\title{
The human right to development as a paradox
}

\author{
By Wouter Vandenhole, Leuven
}

\section{Introduction}

The right to development - most often understood as a human right belonging to the socalled third generation of human rights ${ }^{1}-$ is a problematic concept, politically, conceptually and legally.

From the beginning the right to development has been a highly contested concept politically. Before 1993, in almost every vote on the subject in one of the United Nations bodies, the United States voted against, and some (predominantly Western) states abstained. ${ }^{2}$ A political breakthrough seemed to have been reached on the World Conference on Human Rights in Vienna (1993), where the right to development was for the first time unanimously recognized as a human right. ${ }^{3}$ This consensus however concerned only the political recognition of the existence of a human right to development, not its content nor its legal value.

Civil and political rights are believed to constitute a first generation of human rights. The second generation is composed of economic, social and cultural rights. Rights of the so-called third generation are the right to development, the right to peace, the right to a healthy environment and the right to humanitarian assistance. For a discussion of the three generations of rights, see $K$. Vasak, Pour une troisième génération des droits de l'homme, in: C. Swinarski (ed.), Etudes et essais sur le droit international humanitaire et sur les principes de la Croix-Rouge en l'honneur de Jean Pictet, Genève, 1984, 838-839. For a critique on the generations terminology, see e.g. K. de Feyter, The Right to Development and the Development of Human Rights, Studia Diplomatica 1986, 269 and E. Riedel, Menschenrechte der dritten Dimension, Europäische GrundrechteZeitschrift 1989, 14. For a more general critique on the rights of the third generation, see e.g. $P$. van Dijk, Recht op ontwikkeling; een prioriteitsstelling, NJCM-Bulletin 1981, 136-137.

See e.g. UN Doc. Commission on Human Rights Resolution 4 (XXXV) of 2 March 1979: Belgium, Federal Republic of Germany, France, Israel, Luxembourg, Malawi and United Kingdom abstained; UN Doc. G.A. Resolution 41/128 of 4 December 1986: Denmark, Finland, Federal Republic of Germany, Iceland, Israel, Japan, Sweden and the United Kingdom abstained. Only between 1996 and 2000, Commission on Human Rights Resolutions on the right to development have been adopted without a vote (see UN Doc. E/CN.4/1996/15 of 11 April 1996; UN Doc. E/CN.4/1997/72 of 16 April 1997; UN Doc. E/CN.4/1998/72 of 22 April 1998; UN Doc. E/CN.4/1999/79 of 28 April 1999 and UN Doc. E/CN.4/2000/5 of 13 April 2000).

UN Doc. A/CONF.157/23, Vienna Declaration and Programme of Action, World Conference on Human Rights of 12 July 1993, § 10: "The World Conference on Human Rights reaffirms the right to development, as established in the Declaration on the Right to Development, as a universal and inalienable right and an integral part of fundamental human rights." 
The political consensus also seems to have withered away as soon as new initiatives were taken to elaborate the right to development further. ${ }^{4}$

As far as academic literature on the right to development is concerned, no clear consensus has been reached, not even on the basic issues. Two broad strands of analysis can be distinguished. One strand of scholars has predominantly tried to show on moral and/or philosophical grounds that a right to development does exist. ${ }^{5}$ They have never managed to do so convincingly. Another strand has rather examined the legal status, the content, and the duty and right-bearers of the right to development. The scholars belonging to this strand, too, have failed to come up with a consistent and useful conceptualization.

In spite of, or maybe just because of, the lack of unanimous political recognition - with the exception of the Vienna Declaration and some subsequent Commission resolutions - and of scholarly consensus on the concept and legal status until now, the United Nations' bodies have paid considerable attention to the right to development. From 1977 onwards, it has been permanently on the agenda of the Commission on Human Rights. ${ }^{6}$ Over the years, successive working groups have tried - be it rather unsuccessfully - to define the right and to outline ways of implementation and supervision. ${ }^{7}$ In 1998 a follow-up mechanism con-

The Open-ended Working Group that was established in 1998 did not meet until September 2000 for lack of consensus on the person of the Chairperson (see UN Doc. E/CN.4/2000/21, Note by the secretariat on the proceedings of the open-ended working group on the right to development, submitted in accordance with Commission on Human Rights resolution 1999/79 of 8 March 2000). From 2001 onwards, the resolution of the Commission on Human Rights on the right to development met again with resistance or reticence. In 2001, 2 countries voted against and 3 abstained (UN Doc. E/CN.4/2001/9 of 18 April 2001). In 2002, 15 countries abstained (UN Doc. E/CN.4/2002/69 of 25 April 2002).

5 See for example for a position in favour of the right to development: K. M'Baye, Le droit au développement comme un droit de l'homme, Revue des droits de l'homme 1972, 503-534 at 514530 and K. M'Baye, Le droit au développement, in: R.-J. Dupuy (ed.), Le droit au développement au plan international. Colloque, La Haye, 16-18 Octobre 1979, Alphen a/d Rijn, 1980, 72-93 at 78-88. Against: J. Donnelly, The "Right to Development": How Not to Link Human Rights and Development, in: C. Welch / R. Meltzer (ed.), Human Rights and Development in Africa, Albany, 1984, 261-283 at 275 and 277; J. Donnelly, In Search of the Unicorn: the Jurisprudence and Politics of the Right to Development, California Western International Law Journal 1985, 473-509 at 477 and 482 .

6 See also Ph. Alston, Some Notes on the Concept of the Right to Development, in: D. Premon (ed.), Essais sur le concept de "droit de vivre" en mémoire de Yougindra Khushalani, Brussel, $1988,80$.

The First Working Group of Governmental Experts on the Right to Development (1981-1989) worked on drafting the Declaration on the Right to Development and elaborated concrete proposals for promotion of the right. The Second Working Group on the Right to Development (1993-1996) tried to identify the obstacles to the implementation of the right to development. The 
sisting of an independent expert and an Open-ended Working Group on the Right to Development was eventually established in order to monitor and review progress in the implementation of the right to development. ${ }^{8}$ The independent expert Sengupta has meanwhile produced five reports, in which he mainly focuses on development compacts as a means for implementing the right to development. For lack of consensus on the chairperson, it took the working group almost 2 years to meet. ${ }^{9}$ It has not come up with interesting suggestions yet, and keeps struggling with organisational issues. ${ }^{10}$

It is submitted that the continuing effort of the UN to legally implement the human right to development - most recently by the establishment of the follow-up mechanism mentioned above - should be preceded or at least complemented by thorough analysis of the legal status and content of the right. It does not seem very appropriate to engage in implementation without really knowing whether the human right to development ${ }^{11}$ is a necessary or useful legal concept for the purposes pursued. This is all the more so the case when the elaboration of a convention on the right to development - as suggested by the General Assembly on the occasion of the $50^{\text {th }}$ anniversary of the Universal Declaration of Human Rights ${ }^{12}$, and again in the Open-ended Working Group ${ }^{13}$ - is contemplated: the elaboration of a binding legal instrument does not only require political agreement on the subject, but also profound legal analysis.

Intergovernmental Group of Experts on the Right to Development (1996-1997) elaborated a strategy for the implementation and promotion of the right.

8

9

It met for the first time from 18 to 22 September 2000. The second meeting took place from 29 January till 2 February 2001, the third from 25 February till 8 March 2002. The fourth meeting is scheduled for 3-14 February 2003.

10

Two meetings planned in December 2001 and February 2002 did not take place. Again, the meeting planned for October 2002 was cancelled. Furthermore, there were difficulties concerning the conclusions of the second and third meeting.

11

In what follows, the concept of "human right to development" is used to refer to the right to development as a human right. It should be clearly distinguished from a state right to development.

In its Resolution 9 December 1998, § 21 b, UN Doc. A/RES/53/155 ("to invite the follow-up mechanism, inter alia, to consider the question of elaborating a convention on the right to development") and 17 December 1999, § 21, UN Doc. A/RES/54/175 ("Invites the open-ended working group, inter alia, to consider the question of elaborating a convention on the right to development.”). The suggestion to elaborate a convention is inspired by the fact that the 1986 Declaration on the Right to Development is only a resolution. Legally speaking, a resolution has only recommendatory value: it is not binding. Therefore, the elaboration of a convention on the right to development would enhance its legal status in international law.

13

See UN Doc. E/CN.4/200/28 of 20 March 2002, § 85 b. 
In this article, an attempt will be undertaken to submit the human right to development, which has also been discussed on political and philosophical grounds, to a legal analysis: therefore, the content and subjects will be legally defined. ${ }^{14}$ Different approaches can be taken for a legal conceptualization of the right to development: some scholars reject or question the (human) rights nature of the right to development; ${ }^{15}$ others opt for a minimalistic conceptualization firmly situated within mainstream international human rights law, and a third group proposes a rather maximalistic approach of stretching the human rights concept as far as possible. ${ }^{16}$ In this article an attempt is made to conceptualize the right to development as a human right in such a way that it might be liable to broad legal recognition and wide political acceptance. The concept of the human right to development suggested here is therefore minimalistic: it remains squarely within mainstream thinking of international human rights law.

This will be done without reference to the Declaration on the Right to Development, as contained in a 1986 resolution of the General Assembly (UN Doc. GA Res. 41/128 of 4 December 1986). As this Declaration can be and has been criticized from a legal perspective for being very ambiguous, it does not seem a good starting point for an analysis of the human right to development.

See for example K. de Vey Mestdagh, The Right to Development, Netherlands International Law Review 1981, 53: 'In fact the present UN definition of the right to development, as a human right, should be abandoned."; P. de Waart, State Rights and Human Rights as Two Sides of One Principle of International Law: the Right to Development, in: P. de Waart / P. Peters / E. Denters (eds.), International Law and Development, Dordrecht, 1988, 372: "The ongoing discussion on the right to development shows that indeed the term principle is more appropriate. There is no question of an absolute legal State right or human right to development."; M. Kenig-Witkowska, The UN Declaration on the Right to Development in the Light of its Travaux Préparatoires, in: $P$. de Waart / P. Peters / E. Denters (eds.), o.c., 383: "It must be admitted that the UN Working Group of governmental experts on the right to development preparing the draft declaration faced a very difficult task, by selecting the domain of human rights for the regulation of the right to development at the international law level."; A. Rosas, The Right to Development, in: A. Eide / C. Krause / A. Rosas (eds.), Economic, Social and Cultural Rights. A Textbook, Dordrecht, 1995, 254-255: "The right to development should, perhaps, be seen as an umbrella concept and programme rather than a specific human right."

Examples of a maximalist approach can be found in P. Alston, Some Notes on the Concept of the Right to Development, l.c., 84: "The significance of the right to development should be assessed in terms of its impact on the following issues: (1) the operationalization of economic, social and cultural rights; (2) the implementation of international and collective responsibility for the realization of human rights; (3) the growing emphasis on the human rights of collectivities; (4) the need to relate human rights to the broader structures of national and international society (the development dimension). With respect to each of these issues, the right to development represents a potentially important means by which to enrich the existing body of international human rights law." See also K. de Feyter, The Human Rights Approach to Development, II, University of Antwerp, unpublished Ph.D., 1992, 555-556, who defines the human right to development from a double perspective. The internal dimension implies the right of individuals and peoples (minorities and indigenous peoples) towards the domestic state to participate in the determination of the development policy and in the distribution of the benefits. The external dimension entails positive obligations for third states and the international community. 
In a second section the question then will be addressed whether and how this pragmatically defined human right to development in conformity with mainstream international human rights law could be relevant to either international human rights law and/or development. A paradox will appear. The harder we try to define the human right to development within mainstream legal thinking, the less it becomes relevant to international human rights law and/or development. On the other hand, the harder we try to conceptualize it in a legally more meaningful and therefore more innovative way, the less acceptable it becomes both politically and from a mainstream legal point of view, and therefore the less likely it will ever be conceptualized that way. ${ }^{17}$ It will lead us to the question whether it is to be concluded (at least from a legal perspective) that the human right to development should be abandoned altogether.

In a next section, both the 1986 UN Declaration on the Right to Development and the approach taken by the independent expert will be reviewed in light of the analysis in the previous two sections. From this review it will be concluded that all efforts to legally conceptualize the human right to development in a consistent and useful way are bound to fail: either it is not relevant on the ground, or not feasible politically speaking. It will then be suggested that it might be useful to reconsider the right to development as a state right. In this respect, the approach for implementation suggested by the independent expert may hold some potential, as it refers to an interstate right to development rather than to a human right to development.

\section{The human right to development legally defined}

An attempt will be made to define legally the human right to development in accordance with the mainstream international human rights law concept, so as to make it susceptible to broad legal and political recognition. The mainstream international human rights law concept is therefore first succinctly spelled out.

\section{A. The mainstream international human rights law concept}

The mainstream international human rights law concept can be summarised in three statements:

17

Another approach that could be envisaged is to conceptualise the human right to development in an innovative way, and then to attempt to make it legally and politically more acceptable. This approach seems only worthwhile to be pursued if the human right to development is necessary or at least highly relevant for development at the grassroots. It is submitted here it is not, and therefore, this approach is not taken. 
- human rights are individual rights;

- human rights are claims against the state;

- human rights are interdependent and indivisible. If any prioritization is to be made, civil and political rights (the rights of the so-called first generation) are to be considered the most basic or archetypical rights. ${ }^{18}$

Firstly, human rights are individual rights. ${ }^{19}$ The active subject, the right holder is the individual. Only individuals have human rights:

"If human rights are the rights one has simply as a human being, then only human beings have human rights; if one is not a human being, then by definition one can not have a human right. Because only individual persons are human beings, it would seem obvious that only individuals can have human rights. [...] Economic, social, and cultural rights, as well as civil and political rights, are the rights of individuals." 20

Almost all human rights as recognized in the International Bill of Rights are individual rights. The only exception generally accepted is the right to self-determination. ${ }^{21}$ This right, which is recognized in Article 1 of both 1966 Covenants as a right of peoples, is considered to be a collective right of the whole population of a state before it has gained independence. $^{22}$

Secondly, human rights are claimed against the state. They contain claims from the citizen against the government. After World War II, human rights have been internationalized, as the 1948 Universal Declaration and the 1966 Covenants, among many other human rights declarations and treaties, testify. However, the internationalization of human rights has not

It should be stressed that the mainstream human rights law concept is not necessarily the human rights law concept we adhere to personally, but it is still very much the dominant concept. We believe the concept of human rights itself should be dynamic and susceptible to change under certain circumstances. These conditions for adaptation of the human rights concept are not met in the case of the right to development. For the purpose here, it is therefore important to identify the concept of human rights as it stands in mainstream legal thinking. Likewise, it is acknowledged that new developments put the mainstream concept under pressure. These developments nevertheless have not yet managed to change the mainstream human rights law concept.

See also Ph. Alston, Making Space for New Human Rights: The Case of the Right to Development, in: Human Rights Yearbook, Cambridge, USA, 1988, 24-27.

J. Donnelly, Universal Human Rights in Theory \& Practice, Ithaca, 1989, 20.

Donnelly argues that "it is a right that deserves little attention except in very unusual circumstances." J. Donnelly, Human Rights, Individual Rights and Collective Rights, in: J. Berting / P. $R$. Baehr et al. (eds.), Human Rights in A Pluralist World. Individuals and Collectivities, Westport, 1990, 46.

See $K$. de Feyter, o.c., 342. 
detracted human rights from the citizen-government relationship. Its goal was the "strengthening of the legal protection enjoyed by a citizen against his state". 23

Thirdly, all human rights are indivisible and interdependent. ${ }^{24}$ There is no room for conceptual prioritisation of certain rights or a set of rights. All human rights recognised under international law are equal. A clear recognition of the indivisibility and interdependency of all human rights can be found in Article 5 of the Vienna Declaration and Programme of Action:

"All human rights are universal, indivisible and interdependent and interrelated. The international community must treat human rights globally in a fair and equal manner, on the same footing, and with the same emphasis. [...] [I]t is the duty of States, regardless of their political, economic and cultural systems, to promote and protect all human rights and fundamental freedoms.",25

If any prioritization is allowed for or made, civil and political rights are considered more basic or archetypical than economic, social and cultural rights (the rights of the so-called second generation) and the rights of the third generation, such as the right to development. $^{26}$

\section{B. The human right to development from the mainstream international human rights law perspective}

After having identified the mainstream international human rights law concept, an attempt is now undertaken to define the human right to development in line with it. The underlying idea is that only a human right to development in line with the mainstream human rights law concept is potentially acceptable from a political point of view.

P.H. Kooijmans, Human Rights - Universal Panacea? Some Reflections on the so-called human rights of the third generation, Netherlands International Law Review 1990, 322.

24

J. Donnelly, o.c., 28 and J.-J. Israel, Le droit au développement, Revue Générale de Droit International Public 1983, 38.

25

UN Doc. A/CONF.157/23 of 12 July 1993.

26 For a criticism on the perception of civil and political rights as more basic or archetypical rights, see Alston and Quinn who question "the extent to which the concept of economic, social and cultural rights can and should be artificially moulded so as to fit a predetermined conception of rights which by definition has been tailored to reflect the perceived characteristics of civil and political rights." (Ph. Alston / G. Quinn, The Nature and Scope of States Parties' Obligations under the International Covenant on Economic, Social and Cultural Rights, Human Rights Quarterly 1987,160$)$. 


\section{No prioritization}

As all human rights are indivisible and interdependent, the right to development can never be considered as a prerequisite for the fulfilment of other human rights. ${ }^{27}$ This position is a rejection of the so-called indispensability theory, in which the right to development is considered as indispensable for the exercise of other human rights.

The fundamental equality of all human rights recognized in international law (at least in theory) has to prevent political abuse of the right to development. ${ }^{28}$ No violation of any human right can be justified by submitting that as long as the right to development has not been realized, violation of civil, political, social, economic or cultural rights is inevitable or should be condoned. To the extent that prioritization is allowed for in reality, it is not in favour of the right to development.

The principle of fundamental equality of all human rights does not preclude prioritization in the development of programs and strategies for the realization and implementation of certain human rights. This pragmatic prioritization is inherently limited though, as it cannot allow for the realization of certain rights to the detriment of other rights (standstill principle).

\section{Right-bearers}

It is often submitted that the right to development is not only a right of individuals, but also of groups or peoples, and of states. ${ }^{29}$ The reason for this collective component of the right to development is to be sought in the transfer of interstate issues (like a new international economic order) ${ }^{30}$ into the field of human rights. ${ }^{31}$

See $R$. Rich, The Right to Development as an Emerging Human Right, Virginia Journal of International Law 1983, 320.

Ibid., 321. Rich warns that the indispensability theory allows for justification of widespread abuses of human rights.

See e.g. K. M'Baye, Le droit au développement, l.c., 76-77; R. Rich, The Right to Development as an Emerging Human Right, l.c., 315-316. Youssoufi refers to this phenomenon as a plurality of bearers (see A. Youssoufi, Réflexions sur l'apport de la «troisième génération des droits de l'homme», in : Les droits de l'homme à l'aube du XXI ${ }^{e ̀ ~}$ siècle. Karel Vasak Amicorum Liber, Brussel, 1999, 427-428.

30

The new international economic order (NIEO) was the catchphrase of the " 70 s to indicate the new structure of international economic relations favored by the South. A central idea was the creation of fairer terms of trade for the South due to a reform of the capitalist system.

K. de Feyter, The Right to Development and the Development of Human Rights, l.c., 270. 
First of all, it is impossible to imagine from the mainstream concept of international human rights law how a human right of states is possible. Human rights are meant to protect against the state, or to make claims against the state, but are not rights of states. ${ }^{32}$ Therefore, a state can never enjoy a human right to development. ${ }^{33}$ This is not to say that a right to development of states does not exist. The claim is it does not as a human right. It may well exist as a right of states, ${ }^{34}$ but then it has to be dealt with from an interstate law perspective, not from a human rights law angle.

A more contested issue is whether the human right to development is an individual right, a collective right, or both. This issue raises the more general question whether collective human rights exist, or whether every human right is per se an individual right.

There is no scholarly consensus on this theme. To begin with, much depends on how the concept of collectivity is understood. Some authors prefer the concept of group. A group is then characterised by the fact that is not reducible to the sum of its members: it is not just an aggregate of individuals, but a separate unity on its own. Closely related is the concept of people in the anthropological sense: minorities and indigenous people. ${ }^{35}$ This concept of people (as a unity not identical with nation or state) has to be distinguished from "people" understood as the population of a certain state. Another concept used is that of collectivities. Generally, a collectivity is seen as a collection, an aggregate of individuals. ${ }^{36}$ Finally, some authors state that a collective right is in its essence a right of individuals that presup-

See J. Donnelly, In Search of the Unicorn: the Jurisprudence and Politics of the Right to Development, l.c., 499: "The very term "human rights of States" involves a logical contradiction."

See K. de Vey Mestdagh, The Right to Development, l.c., 48 and 53; P. Leuprecht, Droits individuels et droits collectifs dans la perspective du droit au développement, in: S. Marcus Helmons (ed.), Droits de 1'homme et droit au développement, Louvain-la-Neuve, 1989, 21; P. van Dijk, Recht op ontwikkeling; een prioriteitsstelling, NJCM-Bulletin 1981, 135.

Authors who consider the right to development (also) as a state right include: S. Adelmann, The Right to Development: Problems and Potential, London, Commonwealth Secretariat, 1989, 7 and 13; M. Bedjaoui, Some Unorthodox Reflections on the "Right to Development", in: F. Snyder / P. Slinn (eds.), International Law of Development: Comparative Perspectives, Abingdon, 1987, 9091; K. de Vey Mestdagh, The Right to Development, l.c., 53; P. de Waart, State Rights and Human Rights as Two Sides of One Principle of International Law: the Right to Development, l.c., 373; V. Umbricht, "Right to Development", in: R.-J. Dupuy (ed.), o.c., 96-97; J.-J. Israel, Le droit au développement, l.c., 24-34.

$K$. de Feyter, Het recht op ontwikkeling, in: Ministerie Buitenlandse Zaken (ed.), Belgen over mensenrechten. Een bijdrage tot de Wereldconferentie Mensenrechten, Wenen, 14-25 juni 1993, Brussel, 1992, 11-12; T. van Boven, The Right to Development and Human Rights, The Review. International Commission of Jurists, June 1982, 53. (ed.), o.c., 164. 
poses its exercise by a number of individuals to be meaningful (see for example trade union rights and the right to association and assembly). ${ }^{37}$

Galenkamp distinguishes four conceptualizations of collective rights: (a) the aggregate view, in which collective rights are the rights of an aggregate of individuals (e.g. freedom of association); (b) the social origin view, in which collective rights are understood as the rights of the members of a collectivity (e.g. freedom of religion); (c) the legal fiction view, in which collective rights are rights of collectivities as fictitious entities (e.g. right to national self-determination); and (d) the reality view, in which collective rights are rights of pre-legal, de facto collectivities (e.g. rights of indigenous people). According to Galenkamp, only in the reality view it is right to talk about collective rights, as only there individualism is transcended: only in the reality view, non-reducible rights of a collectivity are dealt with. ${ }^{38}$

For our purposes, we tend to agree with Galenkamp to exclude the rights of the so-called aggregate view and social origin view from the concept of collective rights. These are indeed rather individual rights with a collective connotation than collective rights. From a conceptual point of view, these two categories concern individual rights that become only fully meaningful when exercised by a number of individuals. Theoretically speaking, they presuppose more explicitly than other human rights, other individuals, but they remain individual rights. There will be little discussion whether these two categories of - wrongfully called "collective" - rights are human rights. They belong to the catalogue of human rights recognized under international law. These "collective" rights are more a special category within individual rights than a separate category in addition to individual rights.

As to collective rights not reducible to individual rights (e.g. of indigenous peoples), the dominant perspective seems to be that these group rights are not human rights. To the extent that they are recognized under international law, they are to be considered as a separate category of rights in addition to human rights. ${ }^{39}$

As far as the collective rights from the legal fiction view are concerned, it is submitted that they too have to be considered as collective rights, predominantly for legally pragmatic

K. de Vey Mestdagh, The Right to Development, l.c., 48; H. Gros Espiell, The Right of Development as a Human Right, Texas International Law Journal 1981, 196.

M. Galenkamp, Individualism versus Collectivism. The Concept of Collective Rights, Rotterdam, 1993, 16-19.

39

Ibid., 152-154; see also J. Donnelly, In Search of the Unicorn: the Jurisprudence and Politics of the Right to Development, l.c., 497-498. 
reasons: the right to self-determination as paradigmatic example of this category is recognized as a collective right in international human rights law.

Most debate on the question whether collective rights can be human rights, or whether human rights are in se individual rights, takes place without specifying how collective rights are to be understood and without a well-defined concept of collective rights. Although some scholars argue that human rights can be collective in the light of the pluralist base of international human rights law (i.e. both natural law theory and positivism), ${ }^{40}$ the mainstream perspective tends to stress that conceptually human rights are individual rights. ${ }^{41}$ It seems to consider the right to self-determination as a "historical accident" due to the coincidence of de-colonization and the drafting of the 1966 Covenants. Moreover, it has been argued both by opponents and proponents that the right to development cannot be construed simply as a parallel right to the right to self-determination. ${ }^{42}$ As a consequence, from an mainstream international human rights law perspective the human right to development has to be conceptualized as an individual right. ${ }^{43}$ As an individual right, it may have a collective dimension in its exercise, like some of the human rights recognized under international law. ${ }^{44}$

This conclusion can also draw support from the lack of unanimity on the concept of the right to development in the UN bodies. In the eighties it was believed that "through the discussions on this specific right, the whole concept of collective rights [wa]s put to a

Having in mind the right to self-determination as recognised in both 1966 Covenants. See $P h$. Alston, Making Space for New Human Rights: The Case of the Right to Development, l.c., 28-33; K. de Feyter, o.c., 351-353; P. Leuprecht, Droits individuels et droits collectifs dans la perspective du droit au développement, l.c., 18; R. Rich, The Right to Development: A Right of Peoples?, in: J. Crawford (ed.), The Rights of Peoples, Oxford, 1988, 43-44.

J. Donnelly, In Search of the Unicorn: the Jurisprudence and Politics of the Right to Development, l.c., 497.

42

See K. de Feyter, o.c., 354-357; J. Donnelly, In Search of the Unicorn: the Jurisprudence and Politics of the Right to Development, l.c., 497-500; I. Shivji, The Concept of Human Rights in Africa, London, 1989, 81-83. Abi-Saab on the contrary has stated that both rights are very similar in that "the satisfaction of the collective right is a necessary condition, a condition-precedent or a prerequisite for the materialization of the individual rights." (G. Abi-Saab, The Legal Formulation of a Right to Development, l.c., 171). This position has been rejected here earlier. See also $R$. Rich, The Right to Development: A Right of Peoples?, l.c., 45.

This position is explicitly rejected by Bedjaoui who argues that "an interpretation of the right to development in the context of human rights which, unwittingly or not, take on a largely individual connotation, merely diverts attention from the real problems." See M. Bedjaoui, Some Unorthodox Reflections on the "Right to Development", l.c., 91.

See the so-called "collective rights" in the aggregate and social origin view. 
test." ${ }^{45}$ More than fifteen years later, the discussions on the right to development have not yet been able to clarify the concept of the right. It is therefore hard to escape the conclusion that up till now the concept of collective human rights has been rejected in mainstream international human rights law.

\section{Duty-bearers}

As said earlier, from a mainstream point of view human rights are enforced against the state. The state is the duty-bearer of human rights. With regard to the right to development, some other actors apart from the state are attributed responsibility in literature. No clear distinction is thereby made between the duty-bearers of the human right to development and the right to development as a state right. The duties assigned to other actors than the state range from co-responsibility ${ }^{46}$ or a secondary obligation ${ }^{47}$ for other states to fullfledged responsibility of the international community and/or the developed states ${ }^{48}$ or even all states, multinational companies and all international economic agents. ${ }^{49}$

In light of the mainstream international human rights law concept, only the state is legally bound to respect the human right to development. Other states, the international community or non-state actors do not have legal obligations under the human right to development. As far as the international community is concerned, it has even been argued that it does simply not exist. ${ }^{50}$

K. de Feyter, The Right to Development and the Development of Human Rights, l.c., 282.

K. de Vey Mestdagh, The Right to Development, l.c., 52-53.

See K. de Feyter, o.c., 348 and 351. These obligations could be coined "transnational human rights obligations". The concept has been elaborated recently by Skogly and Gibney, albeit for the narrower issue of obligations of states relating to the human rights effects of their external activities (see S. Skogly / M. Gibney, Transnational Human Rights Obligations, Human Rights Quarterly 2002, 781-798).

G. Abi-Saab, The Legal Formulation of a Right to Development, l.c., 170-171; H. Gros Espiell, The Right of Development as a Human Right, l.c., 199; K. M'Baye, Le droit au développement, l.c., 77; K. M'Baye, Le droit au développement est-il un droit de l'homme?, l.c., 68-69.

S. Chowdhury / P. de Waart, Significance of the right to development: an introductory view, in: $S$. Chowdhury / E. Denters / P. de Waart (eds.), The Right to Development in International Law, Dordrecht, Martinus Nijhoff, 1992, 16-18.

P.H. Kooimans, Human Rights - Universal Panacea? Some Reflections on the so-called human rights of the third generation, l.c., 326. 


\section{4. $\quad$ Nature and substance}

The nature and substance of the human right to development have likewise not yet been conclusively defined. The attempts undertaken to determine the nature and substance of the human right to development can be summarized along two basic lines: some aim at defining the right as an aggregate of existing rights, others consider it to be a procedural right.

A number of authors define the human right to development as the aggregate or synthesis of all existing human rights. ${ }^{51}$ Development as a process is then understood as the progressive realisation of all human rights. ${ }^{52}$ Development as a goal is the full realisation of all human rights. De Vey Mestdagh for example has identified the following minimum levels or basic rights (in the sense of "all rights relating to man's most basic material and non-material needs, without whose realization a dignified existence is not possible") to define development: the right to life, to adequate food, to clothing, to housing and to medical care, and a minimum level of personal security, freedom of thought, conscience and religion. ${ }^{53}$ In addition, a minimum level of opportunities for participation has to be guaranteed through the right to education, the right to participation in cultural and scientific life, the freedom of expression and the right of association and assembly. ${ }^{54}$

De Feyter has argued that the human right to development (in its internal dimension) is a procedural right, namely a right to participate in the national determination of development policy and to participate in the distribution of the benefits resulting from the development efforts. ${ }^{55}$ This approach relies on the conceptualisation of the right to development as found in the Declaration on the right to development. Development itself is not defined in a general way: its definition depends on the outcome of the participatory decision making process. At the core of each definition however, respect for human rights should be included. $^{56}$

G. Abi-Saab, The Legal Formulation of a Right to Development, l.c., 163; K. de Vey Mestdagh, The Right to Development, l.c., 49.

A. Eide, Maldevelopment and "the Right to Development". A Critical Note with a Constructive Intent, in: R.-J. Dupuy (ed.), o.c., 410.

K. de Vey Mestdagh, The Right to Development, l.c., 50. This conceptualisation was borrowed from van Dijk.

54

Ibid., 50-51.

55

56

K. de Feyter, o.c., 555.

K. de Feyter, o.c., 555. 
In order to be susceptible of implementation, the normative content of a right has to be sufficiently precise. ${ }^{57}$ It should be clear that the broader the content of a right is, the more problematic its implementation risks being. In our opinion, the conceptualisation of the human right to development as an aggregate of existing rights (even if reduced to basic rights as suggested by de Vey Mestdagh) is deficient from this perspective: ${ }^{58}$ it is hard to imagine how it could be implemented. Moreover, from a perspective of legal policy one can question what the use is of a right to development as an aggregate right. ${ }^{59}$ Finally, an aggregate of human rights is not itself a human right. ${ }^{60}$

In the light of the contested character of the meaning of development, ${ }^{61}$ defining the right as a participation right seems the conceptualization that allows best for implementation. The question arises however whether we need a new right to ensure participation in development. To this and other questions we turn in the next section.

\section{The added value of a human right to development}

The attempt undertaken above to define the right to development as a human right in line with mainstream international human rights law results in the following conclusions:

- The right-bearer of the human right to development is the individual, not the state or a collectivity;

- The duty-bearer is the state, not the international community, nor the Western states or transnational companies;

- As to the content of the human right to development, it is basically a right to participate in the decision-making process and the benefits of development.

The question arises whether a human right to development conceptualized in this way makes a meaningful contribution to international human rights law and/or to development, and if so, which and how. Different views exist on the contribution made by the human right to development either to international human rights law or development, on both a

See General Assembly Resolution 41/120, 4 December 1986; P. Alston, Making Space for New Human Rights: The Case of the Right to Development", l.c., 36-37.

See also J. Donnelly, The "Right to Development": How Not to Link Human Rights and Development, l.c., 275.

G. Abi Saab, The Legal Formulation of a Right to Development, l.c., 163.

60

K. de Vey Mestdagh, The Right to Development, l.c., 53.

61

No generally accepted definition of development is available. For a relatively recent account see for instance F.J. Schuurman (ed.), Beyond the Impasse: New Directions in Development Theory, London, 1993, 233. 
theoretical and practical level. ${ }^{62}$ Some have argued that the main contribution of the right to development to international human rights law consists of integrating human rights in development. It is said that the right to development links human rights to the development process, ${ }^{63}$ and that it has brought human rights on the development agenda of the UN bodies and programs ${ }^{64}$ and of the World Bank. ${ }^{65}$ In other words, it is said to have turned the development policy and planning at the international level from a basic needs to a (human) rights based approach. ${ }^{66}$

As a human right conventionally defined more in particular, the right to development is said to answer a "pressing need"67 resulting from "the neglect of the individual's right to development in the context of most development planning"68: it would recognize the relevance of individual human rights for development co-operation. ${ }^{69}$ It might be true that the human right to development fosters and promotes a human rights approach to development. That does by no means imply that a new human right is needed for linking human rights to development. ${ }^{70}$ Integrating human rights into development can be encouraged in numerous other ways. Therefore, it cannot be argued that a human right to development is required for favouring a human rights approach to development.

Others have tried to legitimize the right to development by attributing it the potential to solve the structural violation of human rights that underdevelopment is said to be. The

For a more extensive discussion of the potential relevance of the human right to development for either international human rights law or development, see W. Vandenhole, Mensenrechten en ontwikkeling. Pleidooi voor een procedurele benadering, Leiden, Stichting NJCM-Boekerij, 2002, 172-176.

Ph. Alston, Some Notes on the Concept of the Right to Development, l.c., 78; T. van Boven, The Right to Development and Human Rights, 1.c., 55.

Ph. Alston, The Right to Development at the International Level, in: R.-J. Dupuy (ed.), o.c., 111. See also UNDP, Human Development Report 2000, New York, 2000.

See for instance The World Bank, Development and Human Rights: the Role of the World Bank, The World Bank, Washington, D.C., 1998, 39.

P. van Weerelt, The Right to Development: From Rhetoric to a Global Strategy, Human Rights 2/1998, 7 .

67

68

69

70

See for instance A. Eide, Maldevelopment and "the Right to Development". A Critical Note with a Constructive Intent, l.c., 402. 
structural approach to human rights violations ${ }^{71}$ stands for "linking human rights to global issues such as economic and social development and the root causes of human rights violations". ${ }^{72}$ The attention paid to the (elimination) of the root causes of human rights violations is fully legitimate and necessary. The same question however can be raised here as on the link between human rights and development, namely whether a human right is required for that purpose. In our opinion it is highly questionable whether a new human right is the appropriate way for eliminating the root causes of human rights violations.

De Vey Mestdagh has argued that the human right to development is to be viewed as an instrumental right: it assists the more effective implementation of existing human rights:

"Only in this way does it make sense to interpret the right to development as a human right, as it is described by the UN. Just as development is not an aim in itself but a means to an end, the right to development is not a new material right. It should be understood as an instrumental right (or, rather, a right of an instrumental nature). In this sense the right to development may well be a means [...] of exerting pressure on the international community to implement those rights whose existence and substance are not in dispute." 73

De Vey Mestdagh draws a parallel with the right to self-determination, which is in his opinion of a similar instrumental nature. It would be likewise concerned with the realisation of a large number of other rights, namely related with the implementation of the principle of sovereign equality, the freedom to dispose of natural wealth and resources, and the provision of opportunities for individuals to participate in the administration of the state. ${ }^{74}$

It is difficult to see how the right to development as an individual human right can exert additional pressure for the implementation of the existing human rights. In drawing a parallel with the right to self-determination, De Vey Mestdagh might come close to the idea of the right to development as a precondition for the realization of the other human rights. ${ }^{75}$ This would run counter to the current consensus in international human rights law on the equality of human rights and has to be forcefully rejected mainly because of the high risk of

Ph. Alston, Some Notes on the Concept of the Right to Development, l.c., 76; R. Rich, The Right to Development: A Right of Peoples?, l.c., 41-42.

A. Rosas, The Right to Development, l.c., 248. See also R. Rich, The Right to Development: A Right of Peoples?, l.c., 50 and T. Van Boven, The Right to Development and Human Rights, l.c., 51 .

K. de Vey Mestdagh, The Right to Development, l.c., 47-48.

Ibid., 47 , footnote 66 . This parallel with the right to self-determination has also been drawn by a number of other authors.

See Rich, who has pointed out the difference between right to self-determination and right to development in order to avoid this unwanted conclusion (R. Rich, The Right to Development: A Right of Peoples?, l.c., 45). 
abuse. An interpretation of the instrumental nature likely to be more in line with the intention of the author seems to be the "interlocking of the individual with the state and the state with the international community". 76 This interpretation refers to the idea that the right to development is at the same time a human right and a state right, the issue that we now turn to.

It has been submitted that the relevance of the human right to development lies in its linkage with a parallel state right to development. ${ }^{77}$ In this double capacity, the right to development is said to enhance the effectiveness of traditional human rights:

"Its collective and individual dimensions place the government of a developing country in the position of being both a creditor and a debtor. A developing country becomes a creditor because it receives development assistance. It becomes a debtor because it then owes a duty to its people to allow and encourage the full development of individuals." 78

Linking a state right with a human right, it is argued, is situated in the metamorphosis of international law from a law of coexistence to a law of co-operation. ${ }^{79}$

Whereas the idea of linking a human right with a state right cannot be rejected outright from a conceptual point of view, and may have some practical potential for contributing to development, it raises difficult conceptual questions. First of all, a state right to development is strongly underdeveloped conceptually. What kind of responsibility, co-responsibility, secondary obligation or duties would it imply for other states? Which other states would be considered: Western states, all other states, the international community?

Secondly, the nature of the link between a human right and a state right has not yet been conceptualized. It has been claimed that "[t]he right to development puts the international legal community in a much better position to understand the relationship between traditional international law and human rights law." profoundly analyzed nor demonstrated how to conceptualise the link between the human right dimension and the interstate right dimension of the right to development. Given the tremendous conceptual confusion surrounding the right to development, it is difficult to

76

77

Ibid., 48 and 53; P. de Waart, State Rights and Human Rights as Two Sides of One Principle of International Law: the Right to Development, l.c., 372-373; J.-J. Israel, Le droit au développement, l.c., 24.

78

79

80

S. Chowdhury / P. de Waart, Significance of the right to development: an introductory view, l.c., 18. 
believe it might enhance our understanding of the relationship between human rights law and traditional international law.

Apart from the conceptual issues, there is also the question whether a state right to development has been recognised politically and legally. One reason for states in the South to frame their claims to development cooperation in human rights rhetoric has probably been the lack of recognition of an interstate right to development. In any case, there is hardly any evidence in international law for the recognition of a state right to development. ${ }^{81}$ Therefore, most likely a new treaty would be necessary to spell out in a binding way the rights and obligations of developing and developed countries flowing from a state right to development. In order to specify the implications of a state right to development in a less binding or voluntary manner, the idea of development compacts as suggested by the independent expert might merit closer attention (see further).

In conclusion it can be said that the added value of the human right to development, conventionally defined, to either international human rights law or to development, is doubtful if not non-existent. In our opinion, the human right to development can only be made more meaningful when certain elements of the human rights concept are innovated. A paradox then appears however: the more we try to define the right to development as a human right within mainstream international human rights law, the less relevant it becomes to existing international human rights law and/or to development. On the other hand, the more we try to conceptualize it in an innovating way in order to make it legally more meaningful, the less acceptable it becomes politically and legally. So conceptualised as a mainstream human right, it might be acceptable but irrelevant; conceptualised as a right with potential relevance, it becomes legally and politically unacceptable.

Different ways of dealing with this paradox can be imagined. One would be to give absolute priority to political and legal acceptability to the detriment of the innovating elements. This approach may prove rather fruitless, as it renders the human right to development meaningless and useless (as showed higher). The right loses any added value in relation to other human rights. The only conclusion possible would be to abandon the right to development altogether.

On the other end of the range of possibilities lies a radically innovative conceptualization of the human right to development, to the detriment of political and legal acceptability. Quite

K. de Vey Mestdagh, The Right to Development, l.c., 53. Kamto accepts that a state right to development is at present non-existent, but identifies legal starting points in the interdependence of states and the ensuing solidarity thereof (see M. Kamto, Retour sur le 'droit au développement' au plan international: Droit au développement des États?, Revue universelle des droits de l'homme 1999, 1-10). 
some scholars took this option in the eighties. They stressed the right to development's centrality in the ideological and conceptual debate on human rights in the UN. ${ }^{82}$ This approach does not seem to have been particularly fruitful in any respect. In our opinion this approach can only be justified if a thus conceptualised human right to development is deemed necessary or at least crucially important for development in practice. It has never been argued nor shown that that is the case. Most often, the existence of the human right to development is taken for granted, and the only question is then how to confer meaning to the human right to development. We suggest not to consider the human right to development simply as a given that has to be imbued with meaning, but to ask the basic question whether it is necessary or at least extremely important for development at the grassroots. We believe that is not the case, and do therefore not believe much effort should be put in trying to change the political and legal acceptability of a radically innovatively conceptualised human right to development.

A third, middle-of-the-road approach could be to take the human right to development as far as possible conceptually, while remaining within the political and legal consensus. It would start from the assumption that there might be a political consensus possible on the existence of a human right to development. ${ }^{83}$ The question to tackle then would be how to conceptualise the human right to development in such a way so as to secure both political consensus and a degree of meaningfulness for the people of the South. In order to achieve the latter, some conceptual innovations would be necessary. Theoretically, innovations could be imagined to take place on each of the issues dealt with: the right-bearers, the dutybearers and the content of the right. In practice however, innovations may prove to be most relevant (and relatively speaking more feasible from a legal and/or political perspective) on the issue of the duty-bearers. ${ }^{84}$ In what follows, both the UN Declaration on the Right to Development and the approach taken by the independent expert will be examined, in particular in light of this conclusion.

\section{Evaluation of the UN approach}

Ph. Alston, Some Notes on the Concept of the Right to Development, l.c., 74 and 84; K. de Feyter, The Right to Development and the Development of Human Rights, l.c., $282 ; R$. Kiwanuka, Developing Rights: The UN Declaration on the Right to Development, l.c., 261.

As pointed out earlier, it is questionable whether the political consensus reached in 1993 is still prevalent.

84

On the issue of right-bearers, the concept of collective rights appears to be too problematic both politically and conceptually to allow for meaningful progress in the short and medium term. Moreover, it is doubtful whether there is a need for collective rights on the ground. Elsewhere, we have argued that collective human rights litigation procedures are to be preferred over collective rights (see W. Vandenhole, o.c., 133-219 and W. Vandenhole, Human Rights Law and Development: a Procedural Approach, to be published). 
For the evaluation of the UN approach with regard to the human right to development, two sets of documents have been selected: the General Assembly Declaration on the Right to Development (1986), and the five reports of the independent expert (1999-2002). It is argued that they represent two fundamentally different approaches towards the right to development.

\section{A. The Declaration on the Right to Development}

\section{Brief outline of the Declaration}

The UN General Assembly adopted the Declaration on the Right to Development on 4 December $1986 .{ }^{85}$ The US voted against, and eight states abstained. ${ }^{86}$ An elaborate analysis of the Declaration can be found elsewhere. ${ }^{87}$ Here the primary focus is on the dutybearers, but first some attention is paid to the right-bearers and the content of the right.

The right-bearers in the Declaration are "every human person and all peoples" (Article 1, $\S 1$ ). In Article 2, $\S 1$ it is emphasised that "[t]he human person is the central subject of development and should be the active participant and beneficiary of the right to development."

As far as the content of the right to development is concerned, it is said in Article $1, \S 1$ that the "right to development is an inalienable human right by virtue of which every human person and all peoples are entitled to participate in, contribute to, and enjoy economic, social, cultural and political development, in which all human rights and fundamental freedoms can be fully realized." The right implies the full realisation of the right of peoples to self-determination (Art. 1, § 2).

According to the Declaration, the duty-bearers are the following: all human beings, individually and collectively, and states (Art. 2, $\S 2$ and 3). States have however the primary responsibility for the creation of national and international conditions favourable to the realization of the right to development (Art. $3, \S 1$ ). Article 2, 33 clarifies the duty of states at the national level: "States have the right and the duty to formulate appropriate national development policies." Article 8 adds to this that "[s]tates should undertake, at the national level, all necessary measures for the realization of the right to development [...] [and]

UN Doc. A/RES/1986/41/128 of 4 December 1986.

See footnote 2 .

See inter alia K. de Feyter, o.c., 382-403; R. Kiwanuka, Developing Rights: The UN Declaration on the Right to Development, Netherlands International Law Review 1988, 257-272. 
should encourage popular participation in all spheres [...]." In Article 5 it is stipulated that "[s]tates shall take resolute steps to eliminate the massive and flagrant violations of the human rights of peoples and human beings." States should also take steps to eliminate obstacles to development resulting from failure to observe civil and political rights, as well as economic social and cultural rights (Art. 6). The other articles contain a mixture of the duties of states at both the national and the international level, with a strong emphasis on co-operation. States have the duty to co-operate with each other in ensuring development and eliminating obstacles to development (Art. 3, § 3). They have the duty to take steps, individually and collectively, to formulate international development policies. Complementary to the efforts of developing countries, effective international co-operation is essential in providing these countries with appropriate means and facilities (Art. 4). According to Article 6, all states should co-operate with a view to promoting, encouraging and strengthening universal respect for and observance of all human rights and fundamental freedoms for all. They should also promote the establishment, maintenance and strengthening of international peace and security (Art. 8).

\section{Evaluation}

The main observation to be made on the Declaration is that it is such an ambiguous text that many different interpretations can be given to it. It is possible to read either the conventional, or a more innovative human rights concept into the text. A mainstream reading of the Declaration would result in the human person - that is: the individual - as the active subject of the human right to development. As far as the duty-bearers are concerned, the Declaration contains a list of duties and responsibilities for "the states", but it is very ambiguous on the issue whether the domestic state, the states in general, the states of the North or the South, or the international community is envisaged. With De Feyter we submit that the main duty-bearer is the domestic state. From other states, only international cooperation can be expected. ${ }^{88}$ The conventional definition of active and passive subjects has lead De Feyter to conclude that the Declaration remains firmly within the traditional international legal order. ${ }^{89}$ From our perspective, it would mean the human right to development is largely irrelevant. 
Some scholars however have interpreted the Declaration in another way. In the first place, it has been argued that the right-holder in the Declaration is clearly the state. ${ }^{90}$ The content of the right too has been understood in a very broad sense: ${ }^{91}$ internally it would imply appropriate national development policies, respect for all human rights and the elimination of obstacles to development resulting from failure to observe human rights, equality of opportunity for all in gaining access to basic resources, education, health services, food, housing, employment and the fair distribution of income, and the right to participate. Internationally, the duty to co-operate in removing obstacles to development could imply "policy initiatives, transfer of resources, abolition of such situations as apartheid, and the promotion of human rights, peace and security.",92

For our purposes, it is striking that no relevant innovative potential has to be attributed to the Declaration as regards the duty-holders. As the expansion of duty-holders in particular has been identified as the major relevant and feasible innovation, it has to be concluded that the Declaration is bound to remain largely an irrelevant text for international human rights law and the real developmental needs of people in the South.

\section{B. The approach taken by the independent expert}

The independent expert on the right to development, Arjun Sengupta, was appointed in 1998. He is the second component - next to an open-ended working group - of a follow-up mechanism for the right to development. His task consists of presenting to the working group at each of its sessions a study on the current state of progress in the implementation of the right to development. ${ }^{93}$

The independent expert has submitted five studies so far. The first study (July 1999) introduced the idea of developments compacts to realize as a matter of priority three basic

M. Kenig-Witkowska, The UN Declaration on the Right to Development in the Light of its Travaux Préparatoires, l.c., 282-283; I. Shivji, The Concept of Human Rights in Africa, London, 1989, 82.

91 The only conclusion to be drawn from such a broadly defined content is that it includes almost everything and therefore nothing (see also I. Shivji, o.c., 82).

R. Kiwanuka, Developing Rights: The UN Declaration on the Right to Development, l.c., 269270.

UN Doc. Economic and Social Council Decision 1998/269, 30 July 1998. The mandate of the independent expert was extended with 3 years, and that of the working group with one year by the Commission on Human Rights in 2001 (see UN Doc. E/CN.4/2001/9 of 18 April 2001, § 25). The mandate was again prolonged with one year in 2002 (UN Doc. E/CN.4/2002/69 of 25 April 2002, $\S 279)$. 
rights: the right to basic education, the right to food and the right to basic health care. ${ }^{94}$ The second report (September 2000) focused primarily on the issue of poverty. ${ }^{95}$ The third report (January 2001) recapitulated the main issues of the first two reports. ${ }^{96}$ In the fourth report (December 2001), the independent expert concentrated on the methods of implementing the right to development, both on the national and the international level. He spelt out in particular the details of his proposed development compact as a way of operationalising the right to development. ${ }^{97}$ Finally, the fifth report (September 2002) examines the existing mechanisms and frameworks for development cooperation ${ }^{98}$ in light of his proposed development compacts. ${ }^{99}$ In what follows, the relevant aspects of the approach taken by the independent expert are first briefly summarized, and then analyzed in light of the question to what extent his approach is potentially relevant for development.

\section{Brief outline of the approach taken}

In his first study the independent expert made clear that he wanted to spell out a framework in the light of which the document of the Declaration could be operationalized. To that end, he intended to build on the broad existing achievements, without going into the debates and controversies surrounding the Declaration. ${ }^{100}$ His main objective was to make a start with the implementation of the human right to development after almost three decades of discussion. He therefore suggests a program of realizing three minimal rights (namely the right to food, to primary health care and to primary education) by way of an international development compact, as a form of international co-operation in a step-by-step approach, based on reciprocal responsibility for state parties and the international community. ${ }^{101}$ Such a compact should always be complemented by well-designed national programs for growth and development, specially targeted to the poor. ${ }^{102}$

Ibid. $\$ 80$.

UN Doc. E/CN.4/1999/WG.18.2 of 27 July 1999.

UN Doc. E/CN.4/2000/WG.18/CRP.1 of 11 September 2000.

UN Doc. E/CN.4/2001/WG.18/2 of 2 January 2001.

UN Doc. E/CN.4/2002/WG.18/2 of 20 December 2001.

Such as Poverty Reduction Strategy Papers, Comprehensive Development Frameworks, Common Country Assessment and the United Nations Development Assistance Framework.

UN Doc. E/CN.4/2002/WG.18/6 of 18 September 2002.

UN Doc. E/CN.4/1999/WG.18.2 of 27 July 1999, § 16.

Ibid. § 78; UN Doc. E/CN.4/2000/WG.18/CRP.1 of 11 September 2000, § 35. 
As a starting point, the independent expert states in general that "the recognition of the right to development as an inalienable human right is to confer on its implementation a claim on national and international resources and to oblige States and other agencies of society, including individuals, to implement that right". ${ }^{103}$ From the program proposed for realizing the right to development it can be inferred that the domestic state is the only subject against whom the right can be claimed. "The responsibility of states is limited to "the creation of conditions for realizing the right to development, and not necessarily for actually realizing development". 104

Sengupta suggests that international development cooperation could take place in the form of voluntary and consensual development compacts between the donor countries, the financial institutions and the developing countries concerned, in a first phase to realize three basic rights within a specified time period. ${ }^{105}$ A development compact would imply "obligations of following policies and procedures mutually agreed upon and of providing required financial and other assistance as identified". ${ }^{106}$ It is "essentially the acceptance of a mutual obligation. If the developing countries concerned follow fully the obligations of realizing these rights, in accordance with the arrangements worked out with their full participation, the international community, the donors and the financial institutions will meet their part of the obligation by providing the necessary financial, technical and other assistance", the independent expert argues. ${ }^{107}$ Four basic operational elements of "right to development-development compacts" were identified in the fifth study: a rights-based development programme, poverty reduction and social indicator targets, development compacts $^{108}$ and monitoring mechanisms.

The developing countries would have the primary responsibility of implementing the programmes covered by the compact. These programmes would entail obligations regarding fulfilling and protecting rights, in other words they would be rights-based. The obligations for the international community (donor countries, international agencies) would be double: it would have to ensure first that all discriminatory policies regarding trade and finance are

103

Ibid. $\$ 20$.

104

UN Doc. E/CN.4/2000/WG.18/CRP.1 of 11 September 2000, $\$ 12$.

105

UN Doc. E/CN.4/1999/WG.18.2 of 27 July 1999, § 34.

106

107

108

Ibid. $\$ 66$.

Ibid. $\$ 74$.

The steps in the process of instituting a development compact were spelt out in the fourth report (UN Doc. E/CN.4/2002/WG.18/2 of 20 December 2001, §§ 56-74) and reiterated in the fifth (UN Doc. E/CN.4/2002/WG.18/6 of 18 September 2002, § 14). 
removed, and secondly that the additional cost of implementing the rights is properly shared. $^{109}$

These international development compacts should be complemented by policies and actions at the national level. The primary responsibility for implementing the right to development lies with the individual States, the independent expert stresses. ${ }^{110}$ Complementary actions and policies at the national level are inter alia needed to avoid that the attention for the implementation of the right to food, primary health and primary education is not detrimental to the other human rights. Therefore, the implementation of the right to development should be guided by the principles of a rights-based approach, i.e. universality and indivisibility; equality and non-discrimination; participation; and transparency and accountability.

\section{Evaluation}

While accepting and endorsing in general the mainstream international human rights law framework, the independent expert introduces two innovative elements. First, he selects three rights for implementation on a priority base. This prioritization is extensively justified by arguing that it is not at all a prioritization in principle, but only in practice in the light of resource restraints. And even this prioritization in practice implies standstill arrangements with regard to other human rights. Secondly, Sengupta introduces the idea of development compacts between the donor countries, financial institutions and developing countries.

The first innovation can hardly be called one. It is clear that either the meaning of the right to development has to be drastically reduced, or a degree of prioritization has to be accepted in order for the right to be susceptible to implementation. Sengupta has clearly opted for the second solution.

More innovating is the concept of development compacts. It is an attempt to extend the circle of "duty-bearers" from the domestic state to donor states and financial institutions ${ }^{112}$

109 UN Doc. E/CN.4/2000/WG.18/CRP.1 of 11 September 2000, §§ 69-72. The way this could be done is explained in the fourth report (UN Doc. E/CN.4/2002/WG.18/2 of 20 December 2001, $\S \S$ 66 and following).

110

UN Doc. E/CN.4/2002/WG.18/2 of 20 December 2001, § 18.

111

Ibid. $\S 22-31$.

112 It also seems to come closest to the agenda of Southern states when arguing in favour of a right to development, namely of sharing control over the economic international environment ( $R$. Barsh, The Right to Development as a Human Right: Results of the Global Consultation, Human Rights 
on a voluntary base, so as to avoid the discussion on the nature of human rights and on the actors from whom they can be claimed. There are also indications that this approach may be put into practice: the open-ended working group has not managed yet to come up with any new and feasible ideas, and the Commission on Human Rights has asked the independent expert to further explore the idea of development compacts. The idea also corresponds with a new trend in development thinking to contract for development, ${ }^{113}$ in other words to opt for voluntary agreements instead of binding rules, or as the independent expert put it, to go for partnership instead of confrontation. ${ }^{114}$

Earlier in this article we concluded that the extension of the duty-bearers of the human right to development might be the most relevant innovation for development and the one most susceptible to legal and political recognition. Development compacts extend the obligations for development programmes from the domestic state to the donor countries and the financial institutions. The independent expert has expressly argued in favour of establishing the international obligations and duties of the donor countries, the financial institutions and even transnational corporations in the context of development compacts. ${ }^{115}$ In this respect, development compacts could be considered to be an innovative way of broadening the duty-bearers of the human right to development.

It has to be pointed out however that the mutual obligations or "reciprocal conditionalities" as the independent expert calls them, do not arise from the human right to development, but from the development compact freely entered into. The legal basis for the mutual obligations is not the human right to development, but an internationally agreed plan of action freely entered into. Therefore, the obligations would at best be contractual obligations, and any rights arising from it would be contractual rights. From the perspective of the South development compacts would at best create rights for states, not for individuals or groups (contrary to human rights law, which creates rights for individuals, not for states). This would mean that in case of non-fulfilment or breach of the development compact, e.g. by a donor country or an international organisation, only the contract parties (in this case a developing country), not individuals or groups belonging to that country, would be able to bring a claim to the monitoring mechanism. In our view, the concept of a development compact therefore rather refers to an interstate right to development than to a human right

Quarterly 1991, 327-329; Ph. Alston, The Right to Development at the International Level, l.c., 112).

113

See e.g. K. de Feyter, World Development Law. Sharing Responsibility for Development, Antwerp, 2001, 291.

114

UN Doc. E/CN.4/2002/WG.18/2 of 20 December 2001, § 45.

115

Ibid. $\S 52-54$. 
to development. Consequently, development compacts rightly bring back the issue of the right to development to the realm to which it belongs, namely that of interstate rights. ${ }^{116}$

\section{General conclusions}

This article has tried to legally define the human right to development in such a way so as to make it both politically and legally acceptable, and relevant for development. The paradox of a legally defined human right to development is that in order to be meaningful and useful, it needs to break new ground, but in order to enjoy broad acceptance, it needs to be kept within the mainstream international human rights law concept. We first concluded that the best way of dealing with this paradox from a legal perspective is in fact to abandon the idea of a human right to development. From a developmental grassroots perspective, no strong reasons exist for pleading for a human right to development.

Secondly, even if one judges it necessary to preserve the idea of a human right to development, evading the above-mentioned paradox is not easy. The challenge seemed to lie in innovating (and thus making more meaningful) the human right to development without losing out on political acceptability and conceptual rigidity. Extending the circle of the duty-bearers of the human right to development seemed to be the most promising route to be taken, and the development compact suggested by the independent expert appeared to be the most feasible approach to go down that road. ${ }^{117}$ This approach leads however back to where the right to development rightly belongs: the realm of interstate rights.

By way of a final observation we would like to emphasize that the scepticism towards the human right to development is not inspired by indifference for the claims made by people in the South. However legitimate these claims may be, the human right to development seems to be the wrong vehicle from a legal point of view to assert them. The legitimate

116

The question that arises then is whether development compacts are the right instruments to elaborate the state right to development. An exhaustive examination of this question is outside the scope of this paper. It should be noted however that although development compacts deal not only with development assistance but also with measures for a fairer international economic regime, most explicit attention goes to the issue of development assistance. Whereas it seems to be assumed that the other elements of development cooperation - such as trade and market access, debt rescheduling and financial restructuring, technology transfer and transactions in intellectual property - will take place more or less automatically, the operational requirements of the latter issue are spelt out in quite some detail. Development compacts might therefore run the risk of being too focused on development assistance, and too little on structural changes in the global economy.

117

Development compacts hold some potential for enlarging the responsibility for development programmes to other actors than the domestic state, be it on a voluntary base. 
claims of the states of the South for a more just global economic order should be discussed in terms of state claims and rights. For the people of a state, improving the implementation and enforcement machinery for civil, political, economic, social and cultural rights on both the national and international level is believed to be potentially more beneficial for their development aspirations. 